\title{
PENGARUH MOTIVASI GURU TERHADAP KINERJA GURU GUNA MENINGKATKAN STANDAR MUTU SISWA PADA SMK MARDIWACANA OKU TIMUR
}

\author{
Garaika1, Helisia Margahana $^{2}$ \\ ${ }^{1,2}$ Program Studi Manjeman, STIE Trisna Negara OKU Timur, Sumatera Selatan \\ 1,2Jl. MP. Bangsa Raja No.27 Belitang, OKU Timur, Sumatera Selatan, Indonesia \\ E-Mail : garaikastie@gmail.com
}

\begin{abstract}
The purpose of national education, as stated in the law aims to lay the foundation of intelligence, knowledge, personality, character, skills for oneself and further education. Mardiwacana Vocational School East OKU is one of the programs supporting the government, participating in the intellectual life of the nation, motivation is a driving factor that influences human behavior. While what happened at East OKU Mardiwadana Vocational High School, the motivation of teachers changes so that it affects the quality standards of students. The task of a teacher is hard, in addition to being a teacher educator it also becomes a manager that regulates everything related to the administration of learning in the classroom, thus based on the above background, the researcher takes the title Effect of Teacher Motivation on Teacher Performance To Increase Student Quality Stability in Middle School Vocational Mardiwacana East $O K U$.

The purpose of this research is to find out the effect of teacher motivation on teacher performance in order to improve the quality standards of students at Mardiwacana Vocational School East OKU. Based on the results of data processing with SPSS for simple regression analysis obtained the results of the regression equation with $Y=25.672+0.546 X$. Based on the regression equation, it can be analyzed the effect of work motivation on job satisfaction, namely: (1) Constant of 25.672 meaning that if the motivation value is zero, the profitability of job satisfaction increases by $25.672 \%$. (2) Motivation variable regression coefficient of 0.546 means that if motivation has increased by 1 , then the profitability of job satisfaction will increase by 0.546. Positive coefficient means that there is a positive influence between nonmaterial incentives on job satisfaction. (3) From the statistical analysis it can be seen that the value of $R$ Square $(R 2)$ is 0.566 . This shows that the work motivation variable affects $56.6 \%$ of employee job satisfaction, while the remaining $43.6 \%$ is the influence of other independent variables not explained by this research model. Based on the data and analysis qualitatively and quantitatively in this study, a conclusion can be drawn that there is a significant influence of teacher motivation on teacher performance in order to improve the quality of students at the Vocational High School of East OKU Mardiwacana.
\end{abstract}

Keywords: Motivation, performance, quality standards, Vocational High School, East OKU

\begin{abstract}
Tujuan pendidikan nasional, sebagai mana tercantum dalam undang-undang tersebut bertujuan untuk meletakkan dasar kecerdasan, pengetahuan, kepribadian, ahlak, keterampilan untuk diri sendiri dan pendidikan lebih lanjut. SMK Mardiwacana OKU Timur merupakan salah satu program mendukung pereintah, ikut turut serta dalam mencerdaskan kehidupan bangsa, Motivasi merupakan factor penggerak yang mempengaruhi tingkah laku manusia. Sedangkan yang terjadi di SMK Mardiwadana OKU Timur, motivasi guru berubah ubah sehingga mempengaruhi standar mutu siswa. Tugas seorang guru itu berat, selain menjadi seorang pendidik guru juga menjadi menejer yang mengatur segala sesuatu yang berhubungan dengan administrasi pempelajaran di kelas, dengan demikian berdasarkan latarbelakang di atas
\end{abstract}


maka peneliti mengambil judul Pengaruh Motivasi Guru Terhadap Kinerja Guru Guna Meningkatkan Stadar Mutu Siswa Pada SMK Mardiwacana OKU Timur.

Adapun tujuan dari penelitian ini adalah ingin mengetahui Pengaruh motivasi guru terhadap kinerja guru guna meningkatkan standar mutu siswa pada SMK Mardiwacana OKU Timur. Berdasarkan hasil pengolahan data dengan SPSS untuk analisis regresi sederhana diperoleh hasil persamaan regresi dengan $\mathrm{Y}=25,672+0,546 \mathrm{X}$. Berdasarkan persamaan regresi tersebut dapat dianalisis pengaruh motivasi kerja terhadap kepuasan kerja, yaitu: (1) Konstanta sebesar 25,672 artinya jika motivasi nilainya adalah nol, maka profitabilitas kepuasan kerja naik sebesar 25,672\%. (2) Koefisien regresi variabel motivasi sebesar 0,546 artinya jika motivasi mengalami kenaikan sebesar 1, maka profitabilitas kepuasan kerja akan mengalami peningkatan 0,546. Koefisien bernilai positif artinya terjadi pengaruh yang positif antara insentif non material terhadap kepuasan kerja. (3) Dari analisis secara statistik tersebut dapat diketahui bahwa nilai $\mathrm{R}$ Square $\left(\mathrm{R}^{2}\right)$ adalah 0,566 . Hal ini menunjukkan bahwa variabel motivasi kerja berpengaruh sebesar 56,6\% terhadap kepuasan kerja pegawai, sedangkan sisanya sebesar $43,6 \%$ adalah merupakan pengaruh dari variabel bebas lain yang tidak dijelaskan oleh model penelitian ini. Berdasarkan data dan analisis secara kualitatif dan kuantitatif dalam penelitian ini dapat diambil suatu kesimpulan yaitu Ada pengaruh yang signifikan motivasi guru terhadap kinerja guru guna meningkatkan stadar mutu siswa pada SMK Mardiwacana OKU Timur.

\section{Kata kunci : Motivasi, kinerja, standar mutu, SMK, OKU Timur}

\section{PENDAHULUAN}

\section{A. Latar Belakang}

Pada era globalisasi sekaran ini, pendidikam merupakan hal yang sangat bagi seluruh Negara untuk bersaing di dunia internasional. Sebuah tantangan bagi bangsa ini untuk meningkatkan kualitas dan mutu pendidikan. Yang menjadi sorotan utama pendidikan adalah pengembangan mutu pendidikan dan kualitas sumber daya manusia. Sumber daya manusia yang berkualitas dapat di ciptakan melalui pendidikan yang berkualitas. Peningkatan kualitas pendidikan tentunya harus di dukung dengan adanya tenaga pengajar. Komponen yang utama yang paling menentukan system pendidikan adalah guru sehingga mendapat perhatian yang paling utama. Seorang guru harus bias menyesuaikan diri dengan adanya pengembangan ilmu pengetahuan dan teknologi yang cepat.

Pendidikan merupakan salah satu indikotor kemajuan suatu bangsa sehingga pemerintah menuangkannya dalam undang undang dasar yaitu Negara turut serta dalam mencerdaskan kehidupan bangsa dengan demikian pemrintah membuka secara luas untuk rakyatnya mendapatkan pendidikan, baik secara formal maupun informal. Motivasi merupakan factor penggerak yang mempengaruhi tingkah laku manusia. Motivasi yang ada didalam para guru dipastikan akan heterogen didalam bergabung kapada organisasi, hal ini bisa dipengaruhi oleh faktor pendidikan, kepribadian maupun kebutuhannya masing-masing, dengan adanya pemberian insentif akan dapat mempersempit perbedaan tujuan guru sebagai tenaga pendidik, sehingga dapat memotivasi pada diri guru agar bersemangat memberikan dedikasi yang tinggi terhadap SMK Mardiwacana OKU Timur. Hasil identifikasi terhadap kondisi yang terjadi saat ini masih lemahnya motivasi guru sehingga secara langsung maupun tidak langsung akan berimplikasi pada perubahan motivasi guru, yang pada akhirnya mempengaruhi kinerja guru.

Penelitian yang dilakukan oleh (Sanusi 2014) memperolah hasil penelitian Hasil penelitian memberikan penilaian "Belum/kurang baik" terhadap desain perencanaan pembelajaran, dan korelasi antara 
penghantaran proses pembelajaran dan penciptaan pembelajaran bermutu tinggi didapat harga r-hitung 0,672 > r-tabel 0,138 $(\mathrm{dk}=238)$. Dengan menggunakan bantuan program SPSS.17 ditampilkan R2sebesar 0,640 menyatakan bahwa $64 \%$ sumbangan pengaruh desain perencanaan dan penghantaran proses pembelajaran terhadap penciptan pembelajaran bermutu tinggi, sedangkan sisanya sebesar 36\% (100\%-64\%) dipengaruhi oleh faktor lain yang tidak dapat dikontrol dalam penelitian ini. (Sanusi dan Septarina 2016) Hasil analisis data menunjukkan bahwa (1) kepemimpinan berpengaruh signifikan dan positif terhadap kinerja manajerial, (2) pemberdayaan sumber daya manusia secara langsung mempengaruhi kinerja manajerial, (3) tata kelola berpengaruh langsung terhadap kinerja manajerial, (4) kepemimpinan dampak signifikan dan positif pada tata kelola, (5) secara langsung Mempengaruhi budaya organisasi tata kelola yang baik, (6) pemberdayaan sumber daya manusia dampak signifikan dan positif pada. (Ardiana 2017) Hasil penelitian menunjukkan bahwa motivasi kerja berpengaruh secara positif terhadap kinerja guru akuntansi dengan kontribusi sebesar $80,6 \%$, selebihnya sebesar $19,4 \%$ kinerja guru akuntansi ditentukan oleh faktor-faktor lain diluar penelitian. (Haryanti 2017) Hasil pengujian menjelaskan bahwa $t$ hitung sebesar 5,871 > t tabel sebesar 2,048 maka H0 ditolak yang artinya artinya terdapat pengaruh yang signifikan variabel motivasi berprestasi terhadap variabel kinerja guru di SMK Tunas Pemuda.

Sedangkan yang terjadi di SMK Mardiwadana OKU Timur, motivasi guru berubah ubah sehingga mempengaruhi standar mutu siswa. Tugas seorang guru itu berat, selain menjadi seorang pendidik guru juga menjadi menejer yang mengatur segala sesuatu yang berhubungan dengan administrasi pempelajaran di kelas, dengan demikian berdasarkan uraian di atas maka peneliti mengambil judul Pengaruh Motivasi Guru Terhadap Kinerja Guru Guna Meningkatkan Stadar Mutu Siswa Pada SMK Mardiwacana OKU Timur

\section{LANDASAN HIPOTESIS}

\section{TEORITIS}

DAN

\subsection{Teori Motivasi}

(Hasibuan 2011) motivasi berasal dari kata latin movere yang berarti 'dorongan atau daya penggerak'. Motivasi ini hanya diberikan kepada manusia, khususnya kepada para bawahan atau pengikut. Motivasi penting karena dengan motivasi ini diharapkan setiap individu karyawan mau bekerja keras dan antusias untuk mencapai produktivitas kerja yang tinggi.

(Fauzi 2018) mengatakan motivasi adalah keadaan dalam pribadi seseorang yang mendorong keinginan individu untuk melakukan kegiatan- kegiatan tertentu guna mencapai tujuan. Motivasi yang ada pada seseorang akan mewujudkan suatu perilaku yang diarahkan pada tujuan mencapai sasaran kepuasan.

(Fauzi 2013) faktor-faktor yang mempengaruhi motivasi kerja adalah:

1. Faktor internal ( intrisik ) yaitu faktor yang timbul dari dalam diri pegawai tersebut seperti kesenangan bekerja, kesesuaian dengan sekelilingnya, tanggung jawab pribadi.

2. Faktor eksternal ( ekstrinsik ) yaitu faktor yang timbul atau datang dari luar diri pegawai tersebut seperti :

\section{a. Penempatan pegawai.}

Menempatkan pegawai pada posisi yang tepat akan membangkitkan semangat kerja pegawai sehingga tujuan motivasi yaitu peningkatan prestasi dan produktivitas kerja akan tercapai

b. Gaji dan insentif yang diberikan perusahaan.

Gaji adalah imbalan yang diterima atas jasa yang diberikan. Sedangkan insentif merupakan suatu dorongan atau perasaan yang diberikan dengan sengaja kepada para pegawai agar dalam diri mereka 
timbul semangat kerja yang lebih besar untuk berprestasi dalam perusahaan.

\section{c. Lingkungan kerja}

Lingkungan kerja yang baik dan memadai akan membuat pegawai betah dan nyaman berada ditempat kerja sehingga pegawai akan termotivasi untuk meningkatkan kualitas kerjanya.

\subsection{Kinerja}

Kata kinerja merupakan terjemahan dari kata bahasa inggris Performance yang mempunyai arti melakukan, hasil atau tingkat keberhasilan dalam pelaksanaan tugas. Pengertian bebasnya, Kinerja adalah hasil, atau tingkat keberhasilan seseorang dalam melaksanakan tugasnya.

(Paul Hersey 1982) menjelaskan bahwa kinerja merupakan suatu fungsi dari motivasi dan kemampuan. Untuk menyelesaikan tugas atau pekerjaan, seseorang harus memiliki derajat kesediaan dan tingkat kemampuan tertentu. Kesediaan dan keterampilan seseorang tidaklah cukup efektif untuk mengerjakan sesuatu tanpa pemahaman yang jelas tentang apa yang akan dikerjakan dan bagaimana mengerjakannya.

(Gibson 1996) menyatakan bahwa pengertian kinerja merujuk pada tingkat keberhasilan dalam melaksanakan tugas serta kemampuan untuk mencapai tujuan yang telah ditetapkan. Kinerja dinyatakan baik dan sukses jika tujuan yang diinginkan dapat tercapai dengan baik.

Ukuran-ukuran dari Kinerja guru yang dikemukakan oleh (H. John Bernardin 1998) yang dikutip oleh Faustino cardoso gomes dalam bukunya Managemen Sumberdaya Manusia yaitu sebagai berikut :

1. Quantity of work : jumlah kerja yang dilakukan dalam suatu periode yang ditentukan.
2. Quality of work: kualitas kerja yang dicapai berdasarkan syarat-syarat kesesuaian dan kesiapanya.

3. Job Knowledge: luasnya pengetahuan mengenai pekerjaan dan keterampilanya.

4. Creativeness : keaslian gagasan -gagasan yang dimunculkan dan tindakan-tindakan untuk menyelesaikan persoalan-persoalan yang timbul.

5. Cooperation : kesediaan untuk bekerjasama dengan orang lain atau sesama anggota organisasi

6. Dependability : kesadaran untuk dapat dipercaya dalam hal kehadiran dan penyelesaian kerja.

7. Initiative : semangat untuk melaksanakan tugas-tugas baru dan dalam memperbesar tanggungjawabnya.

8. Personal Qualities : menyangkut kepribadian, kepemimpinan, keramahtamahan dan integritas pribadi.

\subsection{Kerangka Pemikiran dan Hipotesis}

Berdasarkan teori yang dikemukakan bila dituangkan dalam paradigma kerangka teori yang berfungsi sebagai penuntun alur pikir dan dasar penelitian ini, maka tergambar pada paradigma dibawah ini:

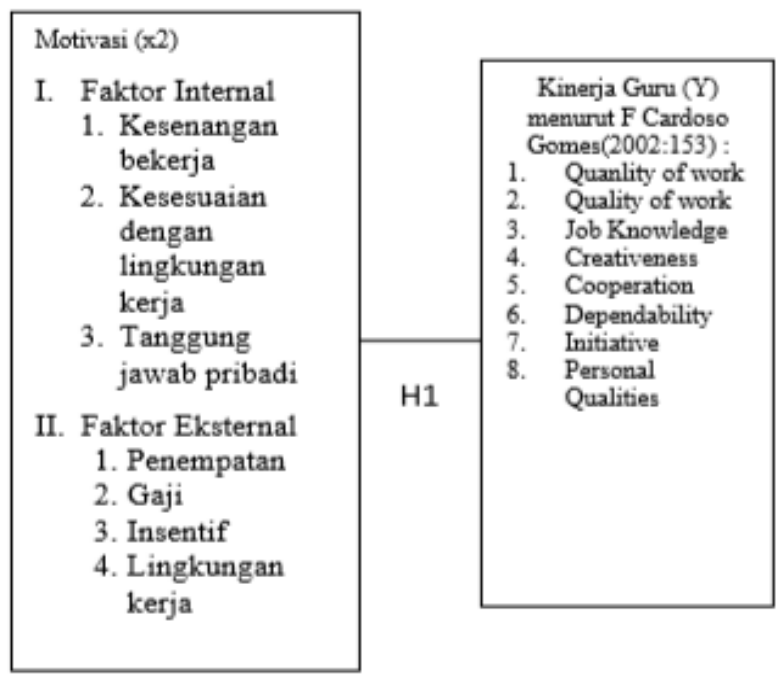


Gambar 1. Kerangka Fikir dan Hipotesis

Adapun hipotesis penelitian ini yaitu Ada pengaruh motivasi guru terhadap kinerja guna meningkatkan strandar mutu siswa pada SMK Mardiwacana OKU Timur

\section{METODOLOGI PENELITIAN}

\subsection{Variabel Penelitian}

Variabel yang digunakan dalam penelitian ini adalah :

1. Variabel terikat (Dependent variabel) adalah variabel yang dipengaruhi oleh variabel lain dalam penelitian ini yang menjadi variabel terikat adalah variabel Kinerja guru (Y).

2. Variabel bebas (Independent Variabel) adalah variabel yang mempengaruhi variabel lain. Dalam penelitian ini variabel bebas adalah Motivasi (x1)

\subsection{Indikator Pengukuran}

Indikator dan parameter yang digunakan pada penelitian ini dapat dilihat pada tabel berikut :

Tabel 1. Variabel dan Indikator Penilaiaan

\begin{tabular}{|c|c|c|}
\hline VARIABEL & INDIKATOR & Pertanyaan \\
\hline \multirow{4}{*}{ 1. Motivasi } & - $\quad$ Kwbutuhan fisik & $1,2,3$, \\
\hline & - keselamatan & $4,5,6$ \\
\hline & - Social & $7,8,9$, \\
\hline & - $\quad$ Aktualisasi diri & $10,11,12,13,14,15$ \\
\hline \multirow{8}{*}{ 2. Kinerja } & - Quanlity of work & \multirow{8}{*}{$\begin{array}{l}1,2,3,4,5,6,7,8,9,10,12,13 \\
14,15,16,17,18,19,20,21,2 \\
2,23\end{array}$} \\
\hline & - Quality of work & \\
\hline & - Job Knowledge & \\
\hline & - $\quad$ Creativeness & \\
\hline & - Cooperation & \\
\hline & - Dependability & \\
\hline & - Initiative & \\
\hline & - $\quad$ Personal Qualities & \\
\hline
\end{tabular}

Pengukuran variabel penelitian digunakan skala likert yaitu sebagai berikut :

1. Sangat Setuju diberi skor 5

2. Setuju diberi skor 4

3. Kurang Setuju diberi skor 3
4. Tidak Setuju, diberi skor 2

5. Sangat Tidak Setuju diberi skor 1

\subsection{Populasi}

Populasi merupakan keseluruhan obyek penelitian sebagai sumber data yang memiliki karakteristik tertentu di dalam suatu penelitian, dan sampel merupakan himpunan bagian dari populasi yang menjadi obyek sesungguhnya. Populasi atau obyek dalam penelitian ini adalah seluruh guru SMK Mardiwacana OKU Timur Untuk mendapatkan sampel yang dapat menggambarkan dan mewakili populasi, maka dalam penentuan sampel digunakan metode sensus hal tersebut berdasarkan petimbangan jumlah populasi sedikit.

\subsection{Metode Pengumpulan Data}

Teknik pengumpulan data dalam penelitian ini dibagi menjadi dua bagian yaitu penelitian lapangan dan penelitian kepustakaan.

\section{- Penelitian Lapangan (Field Reseach)}

Penelitian lapangan dilakukan agar tujuan yang ingin dicapai dapat lebih objektif. Adapun cara yang dilakukan adalah melalui :

a. Wawancara, yaitu pengumpulan data dengan alat pedoman wawancara dilakukan dengan mewawancarai subjek penelitian atau informan.

b. Angket/Kuesioner, merupakan sejumlah pertanyaan secara tertulis yang diajukan kepada responden

- Penelitian Kepustakaan (Library Reseach)

Yaitu teknik pengumpulan data yang bersumber dari literatur, buku-buku maupun laporan-laporan yang relevan dengan tujuan penelitian. 


\subsection{Uji Validitas dan Reliabilitas}

\subsubsection{Uji Validitas}

Menurut Husein Umar (2005) dalam (Ramada 2019) validitas menunjukan sejauh mana suatu alat pengukur itu mengukur apa yang ingin diukur. Jenis validitas yang digunakan yaitu validitas konstruk dimana peneliti mencari definisi-definisi yang dikemukakan para ahli yang tertulis dalam literatur. Metode pengujian validitas instrumen penelitian yang digunakan korelasi product moment dengan rumus sebagai berikut::

$$
r=\frac{n \Sigma x y-\left(\sum x\right)(\Sigma y)}{\sqrt{\left[n \Sigma x^{2}-(\Sigma x)^{2}\right]\left[n \Sigma y^{2}-(\Sigma x)^{2}\right]}}
$$

\section{$\underline{\text { Keterangan : }}$}

$$
\begin{array}{ll}
\mathrm{r}_{\mathrm{xy}} & =\text { keeratan hubungan (korelasi) } \\
\mathrm{x} & =\text { jumlah skor pertanyaan } \\
\mathrm{y} & =\text { jumlah skor total pertanyaan } \\
\mathrm{n} & =\text { jumlah sampel yang akan diuji }
\end{array}
$$

Kriteria keputusan :

$r_{\text {hitung }}>r_{\text {tabel }}$ dan sig. $<0,05$ maka instrumen yang digunakan adalah valid.

$\mathrm{r}_{\text {hitung }}<\mathrm{r}_{\text {tabel }}$ dan sig. $>0,05$ maka instrumen yang digunakan adalah tidak valid.

\subsubsection{Uji Reliabilitas}

Uyanto (2009) dalam (Edward 2014) menyatakan suatu instrumen pengukuran (misal kuesioner) dikatakan reabel bila hasil score yang konsisten pada setiap pengukuran. Suatu pengukuran mungkin reable tetapi tidak valid, tetapi suatu pengukuran tidak bisa dikatakan valid bila tidak reliabel. (Uyanto 2006) Uji reliabilitas menggunakan rumus korelasi alpha conbach dengan menggunakan rumus sebagai berikut :

$$
\alpha_{\text {cronbach }}=\left(\frac{k}{k-1}\right)\left(1-\frac{\sum_{i=1} S_{1}^{2}}{S_{p}^{2}}\right)
$$

Keterangan :

$\mathrm{k}=$ jumlah butir soal dalam skala pengukuran

$S_{t}^{2} \quad=$ ragam (variance) dari butir ke-i

$S_{p}^{2} \quad=$ ragam (variance) dari skor total

Instrumen dapat dikatakan reliabel bila memiliki koefisien kehandalan reliabilitas sebesar 0,6 atau lebih (Uyanto 2006). Perhitungan instrumen penelitian (validitas dan reliabilitas) menggunakan alat bantu program statistik SPSS (Statistikal Product Solution Service) version 17.

\subsection{Analisis Data}

\subsubsection{Analisis Kuantitatif}

Analisis kuantitatif yang dilakukan berdasarkan data primer yang diperoleh dari penyebaran instrumen (daftar pertanyaan) kepada sampel, dan untuk mengetahui pengaruh variabel bebas (independent variable) terhadap variabel terikat (dependent variable). Untuk mengetahui pengaruh motivasi guru (X1) terhadap kinerja guru (Y) dalam penelitian ini menggunakan persamaan regresi sederhana sebagai berikut :

$$
\mathbf{Y}=\mathbf{a}+\mathbf{b}_{2} \mathbf{X}_{2}+\mathbf{e}
$$

Keterangan :

$\mathrm{Y}=$ kinerja guru

$\mathrm{a}=$ konstanta

$\mathrm{b}_{2}=$ koefisien regresi $\mathrm{X}_{2}$

$\mathrm{X}_{2}=$ motivasi guru

$\mathrm{e}=$ faktor kesalahan

\subsubsection{Uji t}

Untuk pengujian hipotesis secara parsial digunakan uji $\mathrm{t}$ dengan rumus 


$$
t_{\text {hitung }}=\frac{r \sqrt{n-2}}{\sqrt{1-r^{2}}}
$$

Dimana :

$\mathrm{t}_{\text {hitung }}=$ nilai $\mathrm{t}$

$\mathrm{r}=$ koefisien korelasi

$\mathrm{n}=$ jumlah responden (Sugiono, 2008:230)

Kriteria uji adalah sebagai berikut :

1. Jika $t_{\text {hitung }}>t_{\text {tabel }}$ maka Ha diterima dan Ho ditolah

2. Jika $t_{\text {hitung }}<t_{\text {tabel }}$ maka Ha ditolak dan Ho diterima

Taraf signifikan dalam penelitian ini digunakan $\alpha=0,05$ atau $5 \%$

Yang dimaksud dengan hipotesis Nol (Ho) dan Hipotesis alternatif $(\mathrm{Ha})$ adalah :

Ho $=r_{1} \leq 0=$ Berarti tidak ada pengaruh antara motivasi guru terhadap kinerja guru

$\mathrm{Ha}=\mathrm{r}_{1} \geq 0=$ Berarti ada pengaruh antara motivasi guru terhadap kinerja guru

\section{HASIL PENELITIAN DAN PEMBAHASAN}

\subsection{Uji Validitas Variabel Motivasi}

Berdasarkan hasil perhitungan validitas pertanyaan variabel motivasi guru ditunjukkan pada kolom $r$ hitung, nilai tingkat validitas untuk setiap pertanyaan variabel motivasi pegawai tertinggi adalah sebesar 0.805 dan terendah adalah sebesar 0,472. Dengan tingkat kepercayaan sebesar 95\% Tabel distribusi $r$ sebesar 0,266, $\mathrm{r}$ hitung > $\mathrm{r}$ tabel maka, setiap pertanyaan pada variabel motivasi dinyatakan telah memenuhi tingkat validitas.

\subsection{Uji Valitidas Kinerja Guru}

Berdasarkan validitas pertanyaan variabel kinerja guru ditunjukkan pada kolom $r$ hitung, nilai tingkat validitas untuk setiap pertanyaan variabel kinerja guru tertinggi adalah sebesar 0,747 dan terendah adalah sebesar 0,414. Dengan tingkat kepercayaan sebesar 95\% diperoleh nilai pada Tabel distribusi $\mathrm{r}$ sebesar 0,266, maka setiap pertanyaan pada variabel kinerja guru dinyatakan telah memenuhi tingkat validitas.

\section{Uji Reliabelitas motivasi}

Reliability Statistics
\begin{tabular}{|r|r|}
\hline $\begin{array}{l}\text { Cronbach's } \\
\text { Alpha }\end{array}$ & N of Items \\
\hline \multicolumn{2}{|c|}{ Output SPSS 17} \\
\hline \multicolumn{2}{|c|}{ Out } \\
\hline
\end{tabular}

Cronbach's Alpha motivasi sebesar 79\% dan total pertanyaan berjumlah 15. Meurut Uyanto stardar Cronbach's Alpha diatas 60\% di nyatakan reliabel. Artinya setiap pertanyaan indikator motivasi guru telah reliabel

Uji Reliabelitas Kinerja guru

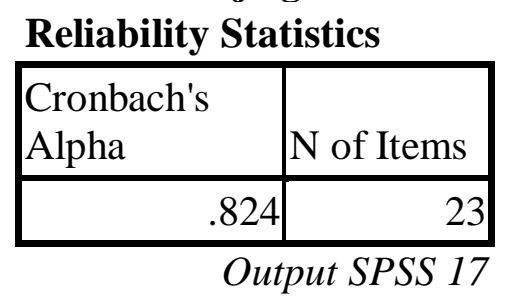

Cronbach's Alpha kinerja sebesar 79\% dan total pertanyaan berjumlah 23. Meurut uyanto stardar Cronbach's Alpha diatas 60\% di nyatakan reliabel. Artinya setiap pertanyaan indicator kinerja guru telah reliable

\subsection{Analisis Kuantitatif}

Analisis data secara kuantitatif dilakukan melalui pendekatan statistik yaitu dengan model analisis regresi sederhana. Alat ini digunakan untuk mengetahui besarnya pengaruh variabel bebas $(\mathrm{X})$ terhadap variabel terikat yaitu $(\mathrm{Y}) \mathrm{di}$ SMK Mardiwacana OKU Timur

\subsection{Analisis Regresi Linier Berganda}

Berdasarkan hasil pengolahan data dengan SPSS untuk analisis regresi sederhana diperoleh hasil persamaan regresi dengan $\mathrm{Y}=$ 25,672+0,546X. Berdasarkan persamaan regresi tersebut dapat dianalisis pengaruh motivasi kerja terhadap kepuasan kerja, yaitu:

1. Konstanta sebesar 25,672 artinya jika motivasi nilainya adalah nol, maka profitabilitas kepuasan kerja naik sebesar $25,672 \%$. 
2. Koefisien regresi variabel motivasi sebesar 0,546 artinya jika motivasi mengalami kenaikan sebesar 1, maka profitabilitas kepuasan kerja akan mengalami peningkatan 0,546. Koefisien bernilai positif artinya terjadi pengaruh yang positif antara insentif non material terhadap kepuasan kerja.

3. Dari analisis secara statistik tersebut dapat diketahui bahwa nilai $\mathrm{R}$ Square $\left(\mathrm{R}^{2}\right)$ adalah 0,566 . Hal ini menunjukkan bahwa variabel motivasi kerja berpengaruh sebesar $56,6 \%$ terhadap kepuasan kerja pegawai, sedangkan sisanya sebesar 43,6\% adalah merupakan pengaruh dari variabel bebas lain yang tidak dijelaskan oleh model penelitian ini.

\subsection{Pengujian Hipotesis}

Perhitungan besaran pengaruh variabel motivasi $\left(\mathrm{X}_{1}\right)$ terhadap kinerja guru $(\mathrm{Y})$ dalam meningkatkan kualitas belajar siswa pada SMK Mardiwacana OKU Timur secara sendiri-sendiri atau parsial digunakan uji t-test. Hasil $t_{\text {hitung }}$ penelitian untuk variabel motivasi $\left(\mathrm{X}_{2}\right)$ sebesar 4,073 lebih besar dari nilai $t_{\text {tabel }}$ sebesar 3,040, dan nilai signifikansi sebesar 0,004 lebih kecil dari 0,025 membuktikan motivasi $\left(\mathrm{X}_{1}\right)$ secara parsial berpengaruh signifikan terhadap kinerja guru (Y) guna meningkatkan stadar mutu siswa pada SMK Mardiwacana OKU Timur,. Dengan demikian disimpulkan hipotesis Ho di tolak dan $\mathrm{H}_{1}$ "di terima".

\subsection{PEMBAHASAN}

Menjawab hipotesis bahwa ada pengaruh motivasi guru terhadap kinerja guru guna meningkatkan standar mutu siswa SMK Mardiwacana OKU Timur. Berdasarkan hipotesis secara parsial dan hasil analisis regresi sederhana motivasi guru terhadap kinerja guru adalah sebagai berikut :

Berdasarkan hasil pengolahan data dengan SPSS untuk analisis regresi sederhana diperoleh Berdasarkan hasil pengolahan data dengan SPSS untuk analisis regresi sederhana diperoleh hasil persamaan regresi dengan $\mathrm{Y}=25,672+0,546 \mathrm{X}$. Berdasarkan persamaan regresi tersebut dapat dianalisis pengaruh motivasi kerja terhadap kepuasan kerja, yaitu:

1. Konstanta sebesar 25,672 artinya jika motivasi nilainya adalah nol, maka profitabilitas kepuasan kerja naik sebesar $25,672 \%$.

2. Koefisien regresi variabel motivasi sebesar 0,546 artinya jika motivasi mengalami kenaikan sebesar 1, maka profitabilitas kepuasan kerja akan mengalami peningkatan 0,546. Koefisien bernilai positif artinya terjadi pengaruh yang positif antara insentif non material terhadap kepuasan kerja.

3. Dari analisis secara statistik tersebut dapat diketahui bahwa nilai $R$ Square $\left(R^{2}\right)$ adalah 0,566. Hal ini menunjukkan bahwa variabel motivasi kerja berpengaruh sebesar 56,6\% terhadap kepuasan kerja pegawai, sedangkan sisanya sebesar 43,6\% adalah merupakan pengaruh dari variabel bebas lain yang tidak dijelaskan oleh model penelitian ini.

Hasil thitung penelitian untuk variabel motivasi $\left(\mathrm{X}_{2}\right)$ sebesar 4,073 lebih besar dari nilai $t_{\text {tabel }}$ sebesar 3,040, dan nilai signifikansi sebesar 0,004 lebih kecil dari 0,025 membuktikan motivasi $\left(\mathrm{X}_{1}\right)$ secara parsial berpengaruh signifikan terhadap kinerja guru (Y) guna meningkatkan stadar mutu siswa pada SMK Mardiwacana OKU Timur.

Berdasarkah hasil penelitian penulis berpendapat bahwa motivasi guru berpengaruh terhadap kinerja guru guna meningkatkan stadar mutu siswa pada SMK Mardiwacana OKU Timu. Pendapat tersebut di dukung oleh teori yang di kemukakan sebagai berikut:

Menurut (Siagian 2005) (Siagian 2004) faktor-faktor yang mempengaruhi motivasi kerja adalah:

1. Faktor internal ( intrisik ) yaitu faktor yang timbul dari dalam diri pegawai tersebut seperti kesenangan bekerja, kesesuaian dengan sekelilingnya, tanggung jawab pribadi. 
2. Faktor eksternal ( ekstrinsik) yaitu faktor yang timbul atau datang dari luar diri pegawai tersebut seperti :

a. Penempatan pegawai.

Menempatkan pegawai pada posisi yang tepat akan membangkitkan semangat kerja pegawai sehingga tujuan motivasi yaitu peningkatan prestasi dan produktivitas kerja akan tercapai

b. Gaji dan insentif yang diberikan perusahaan.

Gaji adalah imbalan yang diterima atas jasa yang diberikan. Sedangkan insentif merupakan suatu dorongan atau perasaan yang diberikan dengan sengaja kepada para pegawai agar dalam diri mereka timbul semangat kerja yang lebih besar untuk berprestasi dalam perusahaan.

\section{c. Lingkungan kerja}

Lingkungan kerja yang baik dan memadai akan membuat pegawai betah dan nyaman berada ditempat kerja sehingga pegawai akan termotivasi untuk meningkatkan kualitas kerjanya.

Ukuran-ukuran dari Kinerja guru yang dikemukakan oleh Bernandin \& Russell (2001) dalam (Ramada 2019) yang dikutip oleh Faustino cardoso gomes dalam bukunya Managemen Sumberdaya Manusia yaitu sebagai berikut :

1. Quantity of work : jumlah kerja yang dilakukan dalam suatu periode yang ditentukan.

2. Quality of work : kualitas kerja yang dicapai berdasarkan syarat-syarat kesesuaian dan kesiapanya.

3. Job Knowledge: luasnya pengetahuan mengenai pekerjaan dan keterampilanya.
4. Creativeness : keaslian gagasan -gagasan yang dimunculkan dan tindakan-tindakan untuk menyelesaikan persoalan-persoalan yang timbul.

5. Cooperation : kesediaan untuk bekerjasama dengan orang lain atau sesama anggota organisasi

6. Dependability : kesadaran untuk dapat dipercaya dalam hal kehadiran dan penyelesaian kerja.

7. Initiative : semangat untuk melaksanakan tugas-tugas baru dan dalam memperbesar tanggungjawabnya.

8. Personal Qualities : menyangkut kepribadian, kepemimpinan, keramahtamahan dan integritas pribadi.

\section{KESIMPULAN DAN IMPLIKASI}

\subsection{Kesimpulan}

Berdasarkan data dan analisis secara kualitatif dan kuantitatif dalam penelitian ini dapat diambil suatu kesimpulan yaitu Ada pengaruh yang signifikan motivasi guru terhadap kinerja guru guna meningkatkan stadar mutu siswa pada SMK Mardiwacana OKU Timur. Dapat terlihat dari hasil analisis regresi sederhana diperoleh hasil persamaan regresi dengan $\mathrm{Y}=25,672+0,546 \mathrm{X}$. Konstanta sebesar 25,672 artinya jika motivasi nilainya adalah nol, maka profitabilitas kepuasan kerja naik sebesar $25,672 \%$. Koefisien regresi variabel motivasi sebesar 0,546 artinya jika motivasi mengalami kenaikan sebesar 1, maka profitabilitas kepuasan kerja akan mengalami peningkatan 0,546. Koefisien bernilai positif artinya terjadi pengaruh yang positif antara insentif non material terhadap kepuasan kerja.

\subsection{Implikasi}

Berdasarkan hasil penelitian terdapat beberapa temuan yang perlu direkomendasikan kepada SMK Mardiwacana OKU Timur dalam 
rangka mengambil langkah-langkah kebijakan untuk meningkatkan kinerja guru yaitu:

1. motivasi yang diterapkan belum optimal masih terdapat guru yang berfasiasi motivasinya sehingga berdampak pada siswa untuk itu sekolah biasa memberikan motivasi penghargaan kepada guru yang berprestasi dan kreatif sehingga guru merasa di hargai

2. kinerja yang diterapkan belum optimal hendaknya perlu ditingkatkan namun demikian kinerja guru telah menunjukkan hasil yang cukup optimal namun perlu dilakukan peningkatan. Peningkatan tersebut adalah dalam hal semangat untuk melaksanakan tugas-tugas baru dan dalam memperbesar tanggungjawabnya.

\section{DAFTAR PUSTAKA}

Ardiana, Titin Eka. 2017. "Pengaruh Motivasi Kerja Guru Terhadap Kinerja Guru Akuntansi SMK Di Kota Madiun." Jurnal Akuntansi dan Pajak 17(02):14-23.

Edward, Puji Rahayu; Muhammad. 2014. "Pengaruh Word Of Mouth Terhadap Keputusan Pembelian Konsumen Produk Smartfren Andromax ( studi pada mahasiswa kampus ketintang Universitas Negeri Surabaya )." Jurnal Pendidikan Tata Niaga 2(1):1-12.

Fauzi. 2013. Manajeman Itu Mudah. Jakarta: Rajawali.

Fauzi, Rita Irviani. 2018. Penagntar Manajeman Edisi Revisi. diedit oleh Putri Chistian. Yogyakarta: Andi Offset.

Gibson, James L. 1996. Organisasi dan Manajemen: Perilaku, Struktur, Proses. Djoerban W.

H. John Bernardin, Joyce E. A. Russell. 1998. Human Resource Management An Experiential Approach Fifth Edition. McGraw-Hill//rwin.

Haryanti, Titik. 2017. "Pengaruh Motivasi Berprestasi Terhadap Kinerja Guru Di SMK Tunas Pemuda." Research and Development Journal Of Education 4(1):44-52.

Hasibuan, Malayu SP. 2011. Manajemen
Sumber Daya Manusia Edisi Revisi. Bumi Aksara.

Paul Hersey, Ken Blanchard. 1982. Manajemen Perilaku Organisasi: Pendayagunaan Sumber Daya Manusia (Edisi Keempat). Jakarta: Erlangga.

Ramada, Ifo. 2019. "Hubungan Komunikasi Interpersonal Dan Motivasi Kerja Dengan Kinerja Karyawan Di PT. MNC Skyvision, Tbk Cabang KPU Pekanbaru." UIN Sultan Syarif Kasim Riau.

Sanusi, Anuar. 2014. "Desain Model Perencanaan Dan Penghantaran Proses Pembelajaran Berdaya Saing Terhadap Penciptaan Pembelajaran Berbasis Mutu Tinggi Berkebelanjutan." Hal. 803-17 in SEMBISTEK 2014 IBI Darmajaya.

Sanusi, Anuar dan Linda Septarina. 2016. "Managerial Performance Model of Private Higher Education in The South Sumatra." Hal. 138-44 in (ICEMAL2016. Vol. 14.

Siagian, Sondang P. 2004. Teori Motivasi dan Aplikasi. Jakarta: Rineka Cipta.

Siagian, Sondang P. 2005. Fungsi-Fungsi Manajerial. Jakarta: Bumi Aksara.

Uyanto, Stanislaus. 2006. Pedoman Analisis Data Dengan SPSS Edisi 2. Yogyakarta: Graha Ilmu. 